\section{FISH-EATING ROBIN}

By PATRICIA R. KERN,

1053 Chestnut Ave., Moose Jaw, Sask.

The winter of 1973-74 was a hard one in Western Canada, with very cold weather and deep snow. As a flood control measure the Moose Jaw city authorities had lowered the water level of Moose Jaw Creek. However, several small areas of the river remained open because of springs or water running swiftly over sand and gravel bars.

On January 10, 1974, a bright cold day. I drove through River and Wellesley Parks in the Moose Jaw Creek Valley in south Moose Jaw. Magpies and several Bohemian Waxwings were drinking from a small open spot in the stream. A Robin flew along, landed at the edge of the ice and dipped its head into the water to catch a small fish about 1-1/2" long from a school swimming in the open water. The Robin threw the fish onto the ice, picked it up and shook it, only to throw it down again three or four times before working it around in its beak so it could be swallowed headfirst. Several fish were caught and eaten on that occasion.

A number of residents in the immediate area, including $\mathrm{Dr}$. $\mathrm{H}$. V. Young, Mr. and Mrs. Wm. Gardner, and Mrs. Dorothy Campbell, observed the Robin using the same procedure in January and February. We all thought this behaviour was very unusual for a Robin, as its food ordinarily consists of $60 \%$ vegetation (fruits, berries and some grass and weed seeds) and $40 \%$ animal, such as beetles, caterpillars, earthworms, cutworms, ants, flies, grasshoppers and so forth.

However, this curious behaviour has been noted several times previously. In A. C. Bent's Life histories of North American thrushes, kinglets, and their allies, he quotes W. Michael's statement that in 1934 a number of Robins was seen feeding on stranded fish at Mirror Lake, Yosemite. Some spotted Robins plunged belly deep into the water to catch a fish while other birds were content to stand on the shore and pluck fish about 2" long when they came into shallow water. They tossed them out onto the beach, mangled them with their bills, beat them on the ground and otherwise softened them before attempting to swallow. Bent also reports that J. C. Phillips in 1927 reported a remarkable instance of Robins catching trout fry at the State Hatchery at Sutton, Mass.

The Moose Jaw Robin visited nearby yards in the next few months with the flock of waxwings. One was observed with a flock of waxwings a mile west along the river, and also one in the city on February 10. This might have been the same Robin as it was not observed at these times in River Park. The Robin apparently survived the harsh winter, perhaps due to its diet of berries and fish.

\section{SIGHT RECORD OF THE SCISSOR-TAILED FL YCATCHER FOR SASKATCHEWAN}

A. J. MacAULAY,

1651 - 11 th Ave., Regina, Sask.

On August 26, 1975, my wife and I observed a Scissor-tailed Flycatcher hawking for insects from a telephone line in the Qu'Appelle Valley, about 4 miles west of Lumsden. The bird was under observation for 25 minutes, beginning at 2 p.m. at a distance of 35 to 45 yards. An excellent view was obtained through 7 x 50 Bushnell binoculars with excellent lighting conditions in hazy sunlight.

The only other sight record for the province was by Mrs. Jean Bradley at Milestone on September 24, 1970 (Blue Jay 29: 34, 1971).

Pelicans at Quill Lakes. Fred Bard 